\title{
ORGANIC COMPOUNDS IN ROAD DUST AND THEIR ASSOCIATION WITH TRAFFIC
}

\author{
1,2Kristina ČABANOVÁ, ${ }^{3}$ Oldřich MOTYKA, ${ }^{3}$ Daniela PLACHÁ, ${ }^{1}$ Jiří MALIŠ \\ ${ }^{1}$ Faculty of Mining and Geology, Institute of Clean Technologies for Mining and Utilization of Raw Materials \\ for Energy Use, VSB - Technical University of Ostrava, Czech Republic, EU \\ ${ }^{2}$ Centre for Advanced Innovation Technologies, VSB - Technical University of Ostrava, Czech Republic, EU \\ kristina.cabanova@vsb.cz; iiri.malis@vsb.cz \\ ${ }^{3}$ Nanotechnology Centre VSB - Technical University of Ostrava, Czech Republic, EU, \\ oldrich.motyka@vsb.cz; daniela.placha@vsb.cz
}

https://doi.org/10.37904/nanocon.2019.8571

\begin{abstract}
Settled road dust was examined to detect the presence of organic compounds. Samples were collected from a road surface near a busy road junction in the city of Ostrava, Czech Republic, once a month from May to October. The six collected samples were analyzed by gas chromatography with mass detection. The correlation analysis divided the analyzed compounds into three distinct groups. The first group, positively correlated with the traffic count consisted of phenanthrene, acenaphthene, indenol (1,2,3-cd) pyrene, benzo(k)fluoranthene, benzo(a)pyrene, benzo(ghi)perylene, benzo(a)anthracene and chrysene, all positively correlated with each other. The second group of compounds, positively correlated with each other but negatively with the traffic count, consisted of dibenzo(ah)anthracene, naphthalene, anthracene, fluoranthene, acenaphthene and fluorene. The third group consisted only of pyrene, which had a positive correlation with most of the compounds from the second group apart from dibenzo(ah)anthracene and was not correlated with the traffic count in any way.
\end{abstract}

Keywords: Organic compounds, road dust, traffic, $\mathrm{PAH}$

\section{INTRODUCTION}

The economic growth is significantly related to the increase in the number of vehicles in the Czech Republic [1], but also worldwide [2]. In the Czech Republic, the number of newly registered passenger cars has increased by approximately 2 and a half million since 1995 [1]. The daily operation of fossil fuel vehicles releases large amounts of pollutants, e.g. metal-based particles, by-products of fuel combustion, and petroleum hydrocarbons [3]. Some of these pollutants remain primarily deposited on the road surface and generate road dust. The road dust, especially in urban areas is, therefore, a mixture of particles from many sources, e.g. brake pad wear, tire wear, road wear, traffic signs, surrounding soil and vegetation, but also industry [4-6]. Naturally, the urban road dust contains a large amount of organic pollutants, especially polycyclic aromatic hydrocarbons (PAHs) [3,7]. Polycyclic aromatic hydrocarbons (PAHs) are a group of multiple compounds with two or more fused benzene rings with or without alkyl substitutes. The greatest amount of PAHs is produced by incomplete combustion of all carbon-containing substances. Pyrogenic PAHs originate from the incomplete combustion of fossil fuels and organics materials [8]. They have been characterized as ubiquitous, toxic, carcinogenic, mutagenic, teratogenic, and are typical anthropogenic pollutants [9-11]. The US Environmental Protection Agency has identified 16 PAHs as priority organic pollutants, namely naphthalene, acenaphthene, acenaphthene, fluorene, phenanthrene, anthracene, fluoranthene, pyrene, benzo(a)anthracene, chrysene, benzo(b)fluoranthene, benzo(k)fluoranthene, benzo(a)pyrene, indeno(123cd)pyrene, dibenzo(ah)anthracene, and benzo(ghi)perylene [9,12]. Of these 16 PAHs substances, Benzo(a)pyrene has been categorized as Group 1 (human carcinogen), and other six are probable 
(2A)/possible (2B) human carcinogens by International Agency for Research on Cancer (IARC) [9,13]. PAHs with a larger number of benzene nuclei have low vapour pressure and practically do not occur freely in the air, but they are sorbed onto solid particles [14]. Larger and heavier particles, to which organic pollutants can bind, tend to sediment. They are whirled by traffic and weather conditions. They are often flushed with rainwater and transported to local watercourses (e.g. streams, rivers and lakes). As a result of this, they may pose a serious risk to aquatic organisms. [9]. Smaller and lighter particles are usually permanently buoyant (below 1 micrometre) and can be easily inhaled [15]. Because of their size, they pose a high risk to the living organisms; if they have organic pollutants bound to them, the risk of course increases. Some studies have shown increased lung, skin, and bladder cancer risks for employees exposed to PAHs [16-21].

The aim of the study was to determine whether there was any dependence between the detected organic pollutants in the settled road dust and the number of vehicles passing through the selected public transport hub and the sampling period (in 2015).

\section{MATERIALS AND METHODS}

\subsection{Sample preparation}

Samples were obtained from an urban crossroad surface in one of the boroughs of the Ostrava City (Czech Republic), town district Poruba. The district is a typical urban site with minimized direct influence of the steel and iron-making industrial complex or other major point sources contributing to the environmental pollution in the rest of the Ostrava City [22]. The sampling site is in the vicinity of a busy intersection and pedestrian crossing, hence, braking is common. Dust samples were collected from $1 \mathrm{~m}^{2}$ road surface, swept using a sampling set in a glass sample container. Samples were collected once per month (from May to October = sample 1-6), between 9:00 and 10:00 in the morning. The day of the sampling was selected depending on the meteorological conditions: sampling was performed only on rainless days after at least two-day period of no wet precipitation. Six samples of 450-500 g per sample were collected. Each sample was homogenized in a rotary mill (Fritsch Pulverisette) at $250 \mathrm{rpm}$ for 15 minutes and, consequently, sieved through a sieve with 200 $\mu \mathrm{m}$ mesh, the organic matter was extracted and subsequently analyzed by gas chromatography with mass detection (GC/MS).

\subsection{Extraction of Organics}

Dichloromethane extractions of investigated organic components were performed by pressurized solvent extraction using Speed Extractor E-916 (Büchi Labortechnik AG, Switzerland). Six $3.00 \pm 0.01 \mathrm{~g}$ samples were extracted in dichloromethane of HPLC grade (Sigma Aldrich) in 3 cycles at $110^{\circ} \mathrm{C}$ and 100 bar. The crude extracts were placed into a vacuum evaporator and concentrated to a volume of approximately $5 \mathrm{ml}$ under nitrogen flow at $40{ }^{\circ} \mathrm{C}$. The resulted extracts were cleaned through a silica gel column chromatography, evaporated to the final volume of $1 \mathrm{ml}$ under nitrogen atmosphere, and immediately analyzed by GC/MS.

\subsection{GC/MS analysis}

A quadrupole mass spectrometer (Agilent Technologies MSD5975C) in connection with a gas chromatograph (Agilent Technologies 7890N) equipped with capillary column DB-XLB $(30 \mathrm{~m} \times 0.25 \mathrm{~mm} \times 0.25 \mu \mathrm{m})$ were used for screening analysis. The GC/MS operating conditions were: the ion source operated in $230^{\circ} \mathrm{C}$, the injection port maintained at $290{ }^{\circ} \mathrm{C}$, and the samples injected in splitless mode followed by 1.5 min purge after the injection. The program column temperature started at $40^{\circ} \mathrm{C}$ for $2 \mathrm{~min}$, then increased by $5{ }^{\circ} \mathrm{C} / \mathrm{min}$ to $300{ }^{\circ} \mathrm{C}$, and was held for $10 \mathrm{~min}$ at $300^{\circ} \mathrm{C}$. The scan mode was employed after additional 6 minutes of delay time. The experimental data were measured in the range of 50-550 atomic mass unit (amu). 


\subsection{Statistical analysis}

The data on the concentrations of PAHs was transformed following the principals of Compositional Data analysis (CoDa) prior to the correlation analysis. Compositional data are non-Euclidean, their transformation into the Euclidean space is required [23], since applying correlation analysis on the raw data may result in spurious correlations [24]. The concentration data matrix was, thus, transformed using centred log-ratio (clr) transformation [25]. Transformations and analyses were performed in the R environment [26] and presented in the form of correlation plot.

\section{RESULTS AND DISCUSSION}

16 organic substances were detected in settled road dust samples. These substances are among the PAHs identified by the US Environmental Protection Agency as priority organic pollutants [9,12]. From the statistical database of the Statutory City of Ostrava in the Czech Republic, which is freely available, we found the average number of vehicles that passed at the place and time of collection [27].

Table 1 Overview of concentrations of polycyclic aromatic hydrocarbons found in samples of settled road dust; naphthalene NAP, acenaphtylene $A C L$, acenaphthene ACE, fluorene FLE, phenanthrene PHE, anthracene ANT, fluoranthene FLU, pyrene PYR, benzo[a]anthracene BaA, chrysene CHR, benzo[b]fluoranthene $\mathrm{BpF}$, benzo[k]fluoranthene $\mathrm{BkF}$, benzo[a]pyrene $\mathrm{BaP}$, indeno[123cd]pyrene $I P$, dibenzo[ah]anthracene DBA, and benzo[ghi]perylene BPE. Values of concentrations in individual months are given.

\begin{tabular}{|c|c|c|c|c|c|c|c|c|c|c|c|c|c|c|c|c|}
\hline ug/kg & NAP & ACL & ACE & FLE & PHE & ANT & FLU & PYR & BaA & CHR & BpF & BkF & BaP & IP & DBA & BPE \\
\hline May & 4.7 & 0.0 & 10.6 & 10.2 & 65.5 & 16.8 & 15.8 & 12.6 & 61.7 & 74.5 & 45.2 & 34.9 & 51.0 & 45.2 & 33.8 & 40.3 \\
\hline June & 6.9 & 0.0 & 12.0 & 8.9 & 47.6 & 13.4 & 11.9 & 85.2 & 46.1 & 59.3 & 38.8 & 28.1 & 41.9 & 38.6 & 26.5 & 33.4 \\
\hline July & 21.8 & 9.4 & 44.8 & 49.1 & 42.7 & 64.2 & 89.7 & 65.1 & 26.3 & 36.7 & 20.2 & 13.0 & 22.1 & 19.2 & 37.9 & 17.7 \\
\hline Aug. & 48.5 & 10.3 & 53.6 & 52.4 & 44.1 & 67.6 & 76.7 & 55.1 & 24.4 & 31.1 & 19.5 & 11.3 & 21.5 & 18.7 & 40.7 & 17.6 \\
\hline Sep. & 54.3 & 9.8 & 38.9 & 43.5 & 35.3 & 53.4 & 65.1 & 48.3 & 22.1 & 30.9 & 18.9 & 11.9 & 21.7 & 17.1 & 38.0 & 17.2 \\
\hline Oct. & 52.6 & 13.2 & 58.7 & 69.4 & 47.3 & 70.1 & 78.9 & 60.6 & 26.2 & 33.3 & 21.3 & 13.3 & 24.3 & 20.7 & 41.0 & 19.2 \\
\hline
\end{tabular}

Table 2 Number of vehicles passing through the selected public transport hub at the place and sampling period (in 2015)

\begin{tabular}{|c|l|l|l|l|l|l|}
\hline \multirow{2}{*}{$\begin{array}{c}\text { Number of cars per month } \\
10^{\wedge} \mathbf{5}(-)\end{array}$} & May & June & July & Aug. & Sep. & Oct. \\
\cline { 2 - 8 } & 4.65036 & 4.71012 & 5.47916 & 4.27332 & 3.0947 & 3.8441 \\
\hline
\end{tabular}

The correlation analysis divided the analyzed compounds into three distinct groups. The first group, positively correlated with the traffic count consisted of phenanthrene, acenaphthene, indeno[1,2,3-cd] pyrene, benzo[k]fluoranthene, benzo[a]pyrene, benzo[ghi]perylene, benzo[a]anthracene and chrysene, all positively correlated with each other. The second group of compounds, positively correlated with each other but negatively with the traffic count, consisted of dibenz[ah]anthracene, naphthalene, anthracene, fluoranthene, acenaphthene and fluorene. The third group consisted only of pyrene, which had a positive correlation with most of the compounds from the second group apart from dibenz[ah]anthracene and was not correlated with the traffic count in any way (Figure 1). The first group comprises mainly PAHs with multiple benzene nuclei 
(Table 1). PAHs with a higher number of benzene cores have low vapour pressure and practically do not occur freely in the atmosphere, but are sorbed onto solid particles [14,28]. Their occurrence positively correlates with traffic (Table 2). The more cars pass through the sampling point, the more these multinucleated organic pollutants will be present in the samples of settled road dust. Conversely, the second group consists mainly of PAHs with two to four benzene nuclei. These PAHs can be sorbed to particles in the atmosphere, but can also be present in the gas phase. Only PAHs having 2-4 benzene rings may be present in the gas phase, (having high vapour pressure at normal temperature) $[14,28]$. This sample group negatively correlates with traffic. More volatile substances are likely to escape into the atmosphere immediately as gases. And those that bind to solid dust particles can escape again by constantly swirling road dust through traffic. The living organism is, therefore constantly exposed to organic substances originating from traffic - whether in the form of gases or in the form of contaminated solid particles of varying size and chemical composition.

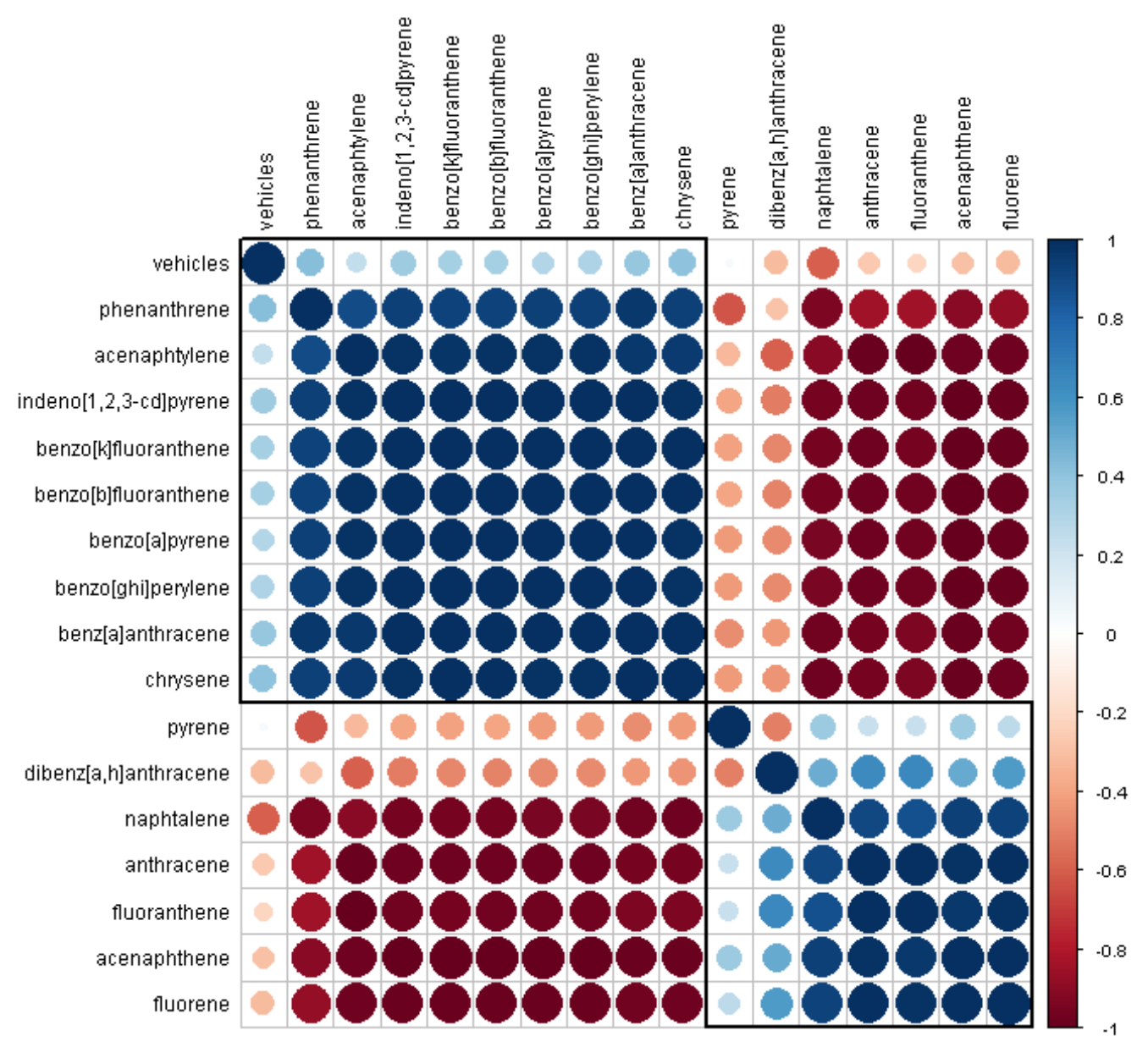

Figure 1 Correlation analysis results

\section{CONCLUSION}

In an industrial area such as Ostrava (Moravian-Silesian Region), there are many sources of organic pollutants. One of the most important is transport. In this study, we managed to demonstrate a certain relationship between these organic pollutants in the settled road dust and the number of vehicles passing through the selected public transport hub and the sampling period (in 2015). There was a significant correlation between the less volatile organic pollutants and traffic, and a negative correlation between more volatile organic pollutants and traffic. These data confirm that many toxic organic pollutants come from heavy traffic. 


\section{ACKNOWLEDGEMENTS}

This study was funded by projects No. L01406. Institute of clean technologies for mining and utilization of raw materials for energy use. National Programme for Sustainability I (2013-2020)

financed by the state budget of the Czech Republic, and by project No.

CZ.02.1.01/0.0/0.0/17_049/0008441 "Innovative therapeutic methods of musculoskeletal system in accident surgery" within the Research and Development for Innovations Operational Programme financed by the European Union.

\section{REFERENCES}

[1] CZECH STATISTICAL OFFICE; Transportation, information and communication - time series. Available from: https://www.czso.cz/csu/czso/dopravni park casove rady ,Tab.2 Silniční doprava_1.8.2019, kód 030019-19; Visited on September 23, 2019.

[2] USDOT. National transportation statistics. Washington, DC: Bureau of Transportation Statistics, United States Department of Transportation. 2015. Available from: https://www.bts.gov/topics/national-transportation-statistics; Visited on September 23, 2019.

[3] HWANG, Hyun-Min, FIALA, Matthew J., WADE, Terry L. and PARK, Dongjoo. Review of pollutants in urban road dust and stormwater runoff: Part II. Organic contaminants from vehicles and road management. International Journal of Urban Sciences. 2018.vol. 23, no. 4, pp. 445-463.

[4] ČABANOVÁ, Kristina, PLACHÁ, Daniela, KUKUTSCHOVÁ, Jana and KUČEROVÁ, Radmila. Chemical and phase analysis of road dust. In: 4th International Conference Nanocon. 2012. pp. 679-684.

[5] ČABANOVÁ, Kristina, HRABOVSKÁ, Kamila, MATĚJKOVÁ, Petra, DĚDKOVÁ, Kateřina, TOMÁŠEK, Vladimír, DVOŘÁČKOVÁ, Jana and KUKUTSCHOVÁ, Jana. Settled iron-based road dust and its characteristics and possible association with detection in human tissues. Environmental Science and Pollution Research. 2019. vol. 26, no. 3, pp. 2950-2959.

[6] HWANG, Hyun-Min, FIALA, Matthew J., PARK, Dongjoo and WADE, Terry L. Review of pollutants in urban road dust and stormwater runoff: Part 1. Heavy metals released from vehicles. International Journal of Urban Sciences. 2016. vol. 20, no. 3, pp. 334-360.

[7] ROGGE, Wolfgang F., MEDEIROS, Patricia M. and SIMONEIT, Bernd R.T. Organic compounds in dust from rural and urban paved and unpaved roads taken during the San Joaquin Valley fugitive dust characterization study. Environmental Engineering Science. 2012. vol. 29, no.1, pp. 1-13.

[8] OZAKI, Noriatsu, AKAGI, Yuma, KINDAICHI, Tomonori and OHASHI, Akiyoshi. PAH contents in road dust on principal roads collected nationwide in Japan and their influential factors. Water Science and Technology. 2015. vol. 72, no. 7, pp. 1062-1071.

[9] KHPALWAK, Wahdatullah, JADOON, Waqar Azeem, ABDEL-DAYEM, Sherif M. and SAKUGAWA, Hiroshi. Polycyclic aromatic hydrocarbons in urban road dust, Afghanistan: Implications for human health. Chemosphere. 2019. vol. 218, pp. 517-526.

[10] LORENZI, Damien, ENTWISTLE, Jane A., CAVE, Mark R. and DEAN, John R. Determination of polycyclic aromatic hydrocarbons in urban street dust: implications for human health. Chemosphere. 2011. vol. 83, no. 7, pp. 970-977.

[11] JADOON, Waqar Azeem; KONDO, Hiroaki, SAKUGAWA, Hiroshi. Distribution and sources of particulate polycyclic aromatic hydrocarbons (PAHs) in air of Kamihaya, central Japan. Geochemical Journal. 2015. vol. 49, no. 2, pp. 207-217.

[12] U.S. EPA, A, 2011. Exposure Factors Handbook 2011 Edition (Final Report). EPA/600/R09/052F.

[13] Some non-heterocyclic polycyclic aromatic hydrocarbons and some related exposures. In IARC Monographs on the Evaluation of Carcinogenic Risks to Humans; International Agency for Research on Cancer: Lyon, France, 2010, ISBN-13 978-92-832-1593-6. Available from: https://monographs.iarc.fr/ENG/Monographs/vol93/mono93.pdf Visited on September 23, 2019. 
[14] POPL, Milan, FÄHNRICH, Jan. Analytická chemie životního prostředí, 4rd ed, Vysoká škola chemickotechnologická, 1999. p. 218.

[15] KUKUTSCHOVÁ, Jana, MORAVEC, Pavel, TOMÁŠEK, Vladimír, MATĚJKA, Vlastimil, SMOLÍK, Jiří, SCHWARZ, Jaroslav, SEIDLEROVÁ, ŠAFÁŘOVÁ, Klára and FILIP, Peter. On airborne nano/micro-sized wear particles released from low-metallic automotive brakes. Environmental Pollution. 2011. vol. 159, no. 4, pp. 998-1006.

[16] SHABBAJ, Ibrahim, ALGHAMDI, Mansour and KHODER, Mamdouh. Street dust-bound polycyclic aromatic hydrocarbons in a Saudi coastal city: Status, profile, sources, and human health risk assessment. International journal of environmental research and public health. 2018. vol.15, no. 11, p. 2397.

[17] PIOLATTO, Pier Giorgio and CATALANI, Simona. The present state of the clinical and epidemiologic research on chemical and carcinogenic risks in the metalworking industry. Giornale italiano di medicina del lavoro ed ergonomia. 2011. vol. 33, no. 3, pp. 239-244.

[18] LIU, Hung-Hsin, YANG, His-Hsien, CHOU, Choa-Da and LIN, Ming-Hsiu. Risk assessment of gaseous/particulate phase PAH exposure in foundry industry. Journal of hazardous materials. 2010. vol. 181, no.1-3, pp. 105-111.

[19] GARATTINI, Siria, SARNICO, Michela, BENVENITI, Alessandra and BARBIERI, Pietro Gino. PAH exposure in asphalt workers. La Medicina del lavoro. 2010. vol. 101, no. 2, pp. 110-117.

[20] CHEN, Szu-Chich and LIAO, Chung-Min. Health risk assessment on human exposed to environmental polycyclic aromatic hydrocarbons pollution sources. Science of the Total Environment. 2006. vol. 366, no.1, pp. 112-123.

[21] KAMEDA, Yutaka, SHIRAI, Junko, KOMAI, Takeshi and NAKANISHI, Junko. Atmospheric polycyclic aromatic hydrocarbons: size distribution, estimation of their risk and their depositions to the human respiratory tract. Science of the Total Environment. 2005. vol. 340, no.1-3, pp. 71-80.

[22] VOSSLER, Teri, ČERNÍKOVSKÝ, Libor, NOVÁK, jiří and WILLIAMS, Ronald. Source apportionment with uncertainty estimates of fine particulate matter in Ostrava, Czech Republic using Positive Matrix Factorization. Atmospheric Pollution Research. 2016. vol.7, no. 3, pp. 503-512.

[23] PAWLOWSKY-GLAHN, Vera, BUCCIANTI, Antonella. Compositional data analysis. Chicester, West Sussex, Hoboken, N.J., Wiley, 2011. p. 378.

[24] PEARSON, Karl. Mathematical contributions to the theory of evolution.-on a form of spurious correlation which may arise when indices are used in the measurement of organs. 1st ed. Proceedings of the royal society of London, 1896, vol. 60, pp. 359-367, pp. 489-498.

[25] AITCHISON, John. The statistical analysis of compositional data. Journal of the Royal Statistical Society: Series $B$ (Methodological). 1982. vol. 44, no. .2, pp. 139-160.

[26] R Core Team. R: A language and environment for statistical computing. R Foundation for Statistical Computing, Vienna, Austria. 2019. Available online at https://www.R-project.org/.

[27] STATUTORY CITY OSTRAVA. Number of cars in the selected transport node in Czech Republic (in 2015, city district Ostrava-Poruba), Available from: https://opendata.ostrava.cz/category/datove-sady/doprava/; Visited on September 23, 2019.

[28] GOLDFARB, Jillian L., SUUBERG, Eric M. Vapor pressures and enthalpies of sublimation of ten polycyclic aromatic hydrocarbons determined via the Knudsen effusion method. Journal of Chemical \& Engineering Data. 2008. vol. 53, no..3, pp. 670-676. 